\title{
Soğanda (Allium Cepa) Azot ve Kükürtlü Gübre Uygulamalarının Yaprak Mineral Madde İçeriği Üzerine Etkisi* *
}

\author{
Barıș ALBAYRAK $1 *$ \\ Ö. Lütfü ELMACl²
}

'Atatürk Bahçe Kültürleri Merkez Araștırma Enstitüsü, YALOVA

${ }^{2}$ Ege Üniversitesi, Ziraat Fakültesi, Toprak Bilimi ve Bitki Besleme Bölümü, İMirR

\begin{abstract}
*Sorumlu yazar e-mail (Corresponding author e-mail):barissalbayrak@hotmail.com
Geliș tarihi (Received) : 14.03.2017

Kabul tarihi (Accepted): 15.03.2017

DOI : $10.21657 /$ topraksu.339831
\end{abstract}

\section{Öz}

Bu çalıșma, soğanda artan dozlarda azot ve kükürt uygulamalarının yaprakların mineral madde içeriği üzerine etkisini belirlemek amacıyla 2012 ve 2013 yıllarında Yalova Atatürk Bahçe Kültürleri Merkez Araștırma Enstitüsü deneme alanlarında yürütülmüștür. Denemede, azotun 0-5-10-20 kg da'-1 dozları ile kükürdün 0-2.5-5-10 kg da-1 dozlarının kombinasyonları uygulanmıștır. Çalıșmada gübre uygulamalarının soğan yapraklarının azot, fosfor, potasyum, kalsiyum, magnezyum ve kükürt içerikleri üzerine etkileri incelenmiștir. Yapılan değerlendirmeler sonucunda, azotlu gübrenin yaprakların azot içeriği üzerine etkisi önemli bulunmuștur. Azot dozları arttıkça yaprağın azot içeriği artmıștır. En yüksek

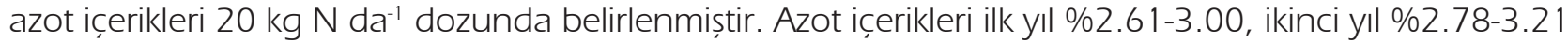
arasında bulunmuștur. Yaprak fosfor içerikleri ile azot dozları arasındaki ilișki ilk yıl önemli çıkmıștır. İkinci yıl fosfor içerikleri ile gübre uygulamaları arasındaki ilișki önemsizdir. Yapılan gübrelemelerin yaprakların potasyum, kalsiyum, magnezyum ve kükürt içerikleri üzerine etkisi istatistiksel olarak önemsizdir. Yıllara göre sırasıyla yaprakların mineral madde içerikleri fosfor için \%0.16-0.19, \%0.19-0.21; potasyum için \%3.60-4.12, \%3.46-3.94; kalsiyum için \%2.85-3.35, \%2.99-3.41; magnezyum için \%0.34-0.44, \%0.36-0.39 ve kükürt için \%0.53-0.79, \%0.66-0.69 arasında belirlenmiștir.

Anahtar Kelimeler: Azot, kükürt, mineral madde, soğan, yaprak

\section{The Effect of Nitrogen and Sulphur Fertilizer Applications on The Content of Leaf Mineral Matter of Onion (Allium cepa L.)}

\begin{abstract}
The aim of this study was to determine effect of nitrogen and sulphur applications on mineral content of of onion's leaf. The study was carried out in Atatürk Central Horticultural Research Institute in the years of 2012 and 2013 in Yalova. The fertilizer were applied in combination of N, S and rates of the N-S combinations were 0-50-100-200 kg N ha-1 and 0-25-50-100 kg S ha-1. The effects of fertilizer applications on nitrogen, phosphorus, potassium, calcium, magnesium and sulphur content of leafs were determined in the study. Nitrogen content of leaf was significantly affected by applied nitrogen. Nitrogen content of leaf was increased by higher doses of nitrogen fertilization. There was no effect from sulphur fertilization. Both year, the highest nitrogen content were determined by $20 \mathrm{~kg} \mathrm{~N} \mathrm{da}^{-1}$ dose. The nitrogen content of first and second year was 2.61-3.00\% and 2.78-3.21\% respectively. The relation between nitrogen fertilization and leaf's phosphorus content were significant in the first year; but second year not. Additionally, the effect of nitrogen and sulphur fertilization on potassium, calcium,
\end{abstract}


magnesium and sulphur content were statistically unsignificant. They were determined between 0.16$0.19 \%, 0.19-0.21 \%$ for $\mathrm{P} ; 3.60-4.12 \%, 3.46-3.94 \%$ for $\mathrm{K} ; 2.85-3.35 \%, 2.99-3.41 \%$ for Ca; $0.34-0.44 \%$, $0.36-0.39 \%$ for $\mathrm{Mg}$ and $0.53-0.79 \%, 0.66-0.69 \%$ for $\mathrm{S}$ at 2012 and 2013 respectively.

Key words: Nitrogen, sulphur, mineral matter, onion, leaf

** “Soğanda (Allium cepa) Azot ve Kükürt Uygulamalarının Verim, Beslenme ve Bazı Kalite Kriterleri Üzerine Etkisinin Araștırıması" adlı Doktora tezinin bir bölümüdür.

\section{GíRiș}

Soğan, dünyanın farklı bölgelerinde yetiștirilebilen ve çok farklı șekillerde tüketilebilen; 4000 yıldan daha uzun bir süredir yetiștiriciliği yapılan bir sebzedir (Lawande, 2010). Soğanın esas anavatanı Akdeniz havzasından bașlar İran ve Afganistan'a kadar uzanır. Alliaceae familyasına ait olan soğanın en yaygın bilinen ve yetiștiriciliği yapılan türü, Allium cepa L. türüdür (Robinowitch ve Brewster, 1990).

Soğan çok uzun zamandan beri sindirim sisteminin düzenlenmesinde, hafif yanık ve nefes darlığı tedavilerinde ilaç niyetine kullanıımaktadır. Soğanın kanın pıntılașması, damar sertleșmesi, kolesterol, romatizmal ağrılar gibi hastalıklar üzerine olumlu etkisi vardır. Ayrıca soğanın yapısında bulunan iso-allisinler kanda trombosit birikimini engeller (Kawakishi ve Morimutsu, 1994). Soğanın 100 g'ında $1.2 \mathrm{~g}$ protein, $0.1 \mathrm{~g}$ yağ, $8.9 \mathrm{~g}$ șekerli maddeler, $8 \mathrm{~g}$ su, $12 \mathrm{~g}$ kuru madde, 30 mg kalsiyum ve 42 kalori bulunur (Beșirli vd., 2007). Diğer taraftan soğanda bulunan ve allilik sülfitler olarak da bilinen maddeler insanda bağıșıklık sistemini güçlendirir, karsinojenlerin vücuttan atılımını arttııır ve tümör hücre çoğalmasını baskılayan enzimleri uyararak, koruyucu etki yaparlar (Aksoy, 2010).

Türkiye kuru soğan üretimi bakımından önemli ülkelerden biri olup; toplam üretimin yaklașık \%2'sini karșılar. Türkiye dünya kuru soğan üretiminde ilk on ülke arasında yer almaktadır. Dünyadaki toplam üretim miktarı 2014 yılında 88475089 tondur, aynı yıl Türkiye üretimi ise 1790000 ton olarak gerçekleșmiștir (Anonim, 2017 a).

Türkiye'de Doğu Anadolu bölgesi hariç hemen her bölgede kuru soğan yetiștiriciliği yapılmakla beraber, üretim yoğun olarak icç Anadolu, Akdeniz'in Doğusu, Orta Karadeniz ve Marmara Bölge'sinde yapılmaktadır (Anonim, 2007). Türkiye'de soğan üretimi 2015 yllında 1879189 ton olarak gerçekleșmiștir. Aynı yıl Marmara Bölgesi toplam üretimin \%15.48'ini sağlamıștır. Marmara
Bölgesi'nde 2015 yllında 290845 ton kuru soğan üretimi yapıımıștır (Anonim, 2017 b).

Pazarlanabilir soğan üretiminde yüksek verim ve homojen baș büyüklüğü en önemli iki kriterdir (Krishnamatuhy ve Sharanappa, 2005). Bitki besin maddeleri, ürünlerin verimliliğinin arttırımasında ve kaliteli ürün elde edilmesinde önemli role sahiptir. Kuru soğan üretiminde ürün miktarının ve kalitenin arttırıması ana hedef haline gelmiștir.

Yapılan araștırmalar göstermiștir ki soğanın kimyasal yapısı üzerine genetik, çevre ve hasat sonrası faktörler etkilidir. Çevre faktörleri içerisinde kükürt ve azot en önemli role sahip olan etmenlerdir (Randle, 1992, 2000; McCallum vd., 2005).

Soğan gibi bütün bitkiler için azot büyüme ve verimlilik açısından son derece önemlidir. Azot verimin yanında bașların kalitesi, olgunluğu, dayanımı ve depolanması üzerine etkindir. Bunun yanı sıra hastalık ve zararlılara dayanıkııık üzerine de çok önemli etki yapar. Azot eksikliği durumunda verimde azalma, baș çap/yüksekliklerinde küçülme görülür ve pazarlanabilir baș oranı düșer. Azot eksikliğinde bașların olgunlașması gecikir, olgunlașan bașların depolama potansiyeli düșer. Fazla azotlu gübreleme de verim ve kaliteyi bozar, sürmeyi ve bitkinin gelișimini etkiler, olgunlașmayı geciktirir ve depolamayı olumsuz etkiler (Brown, 2000). Azotun verim üzerine olumlu etkileri Türkiye'de ve dünyada daha önceki çalıșmalarda ortaya konmuștur (Kaptan vd., 1983; Demir ve Noyan, 1997; Tiwori vd., 2002).

Kükürt bir makro element olup soğan ve diğer allium türleri üzerinde önemli etkilere sahiptir (Bloem vd., 2004; McCallum vd., 2005; Al-Frahiat, 2009). Toprağa uygulanan kükürdün toprak pH'sını düșürücü, toprak-su ilișkilerini düzenleyici ve $\mathrm{P}, \mathrm{Fe}, \mathrm{Mn}$ ve $\mathrm{Zn}$ gibi besin elementlerinin topraktaki yarayıșıııı̆ını arttırıcı etkileri vardır (Marschner, 1998). 
Toprak besin ortamındaki katyonik besin elementi konsantrasyonun $\left(\mathrm{NH}_{4}^{+}, \mathrm{Ca}^{+2} \mathrm{gb}\right)$ artmasının bitki dokusundaki diğer katyonların konsantrasyonlarının azalmasına sebep olabilir. Katyonlar arasında antagonizm, daha az oranda anyonlar anyonlar $\left(\mathrm{NO}_{3}{ }^{-}, \mathrm{SO}_{4}^{-2} \mathrm{gb}\right)$ arasında da söz konusudur (Korkmaz ve Saltalı 2012, Mengel ve Kirkby, 2001)

Soğan hafif bünyeli, geçirgen, organik madde bakımından zengin topraklarda iyi gelișim gösterir. Toprak pH'sına karșı orta derecede hassas olup ideal pH isteği 6-7 arasında bulunmaktadır. Soğan su stresine, tuzluluğa, sodyum ve bor toksisitesine karșı son derece hassastır (Brown, 2000). Soğan üretiminde, toprak verimliliğini toprak reaksiyonu $(\mathrm{pH})$, toprak kireci, tuzluluğu, organik maddesi, toprağın su tutma ve havalanma kapasitesi ile toprakta bulunan makro ve mikro besin elementlerinin miktar ve oranları etkiler (Beșirli vd., 2007).

Bu çalıșmanın temel amacı farklı azot ve kükürtlü gübre uygulamalarının soğan (Allium сера, L.) yapraklarının azot, fosfor, potasyum, kalsiyum, magnezyum ve kükürt içerikleri üzerine etkisini belirlemektir. Bu amaçla 2 yıl yürütülen tarla denemeleriyle yaprakların mineral içerikleri üzerindeki farklılıklar ortaya konulmuștur.

\section{MATERYAL VE METOT}

Azot ve kükürt uygulamalarının kuru soğanın yapraklarının mineral içerikleri üzerine etkisinin belirlenmesi amaciyla yapılan bu çalıșma; Yalova Atatürk Bahçe Kültürleri Merkez Araștırma Enstitüsü'nde 2012-2013 yıllarında, farklı parsellerde, tarla denemeleri șeklinde yürütülmüștür.

\section{Materyal}

Denemede bitki materyali olarak Atatürk Bahçe Kültürleri MerkezAraștırma Enstitüsü'nce geliștirilen ve tohumdan baș bağlayan Kantartopu-3 soğan çeșidi kullanılmıștır. Kantartopu-3 soğan çeșidi tohumdan baș bașlayabilen bir soğan çeșididir (Anonim, 2014 a). Çalıșmada gübre kaynağı olarak azot için; Amonyum nitrat (\%33 N) kullanılmıștır. Denemede fosfor ve potasyum kaynağı olarak MKP (Mono potasyum fosfat, \%52

Çizelge 1. Deneme parselinin bazı toprak özellikleri (2012-2013)

Table 1. Some chemical propeties of trial soil (2012-2013)

\begin{tabular}{|c|c|c|}
\hline \multirow{2}{*}{$\begin{array}{l}\text { Toprak Özelliği } \\
\text { Soil Property }\end{array}$} & \multicolumn{2}{|c|}{$\begin{array}{l}\text { Yillar } \\
\text { Years }\end{array}$} \\
\hline & 2012 & 2013 \\
\hline $\begin{array}{l}\text { Bünye } \\
\text { Texture }\end{array}$ & $\begin{array}{l}\text { Kumlu tın (SL) } \\
\text { Sandy Loam }\end{array}$ & $\begin{array}{l}\text { Kumlu Killi Tın (SCL) } \\
\text { Sandy Clay Loam }\end{array}$ \\
\hline $\begin{array}{l}\mathrm{EC}\left(\mathrm{dS} \mathrm{m}^{-1}\right) \\
\text { Electrical Conductivity }\end{array}$ & 0.09 & 0.11 \\
\hline $\mathrm{pH}$ & 7.09 & 7.36 \\
\hline $\begin{array}{l}\text { Kireç (\%) } \\
\text { Lime }\end{array}$ & 0.20 & 1.03 \\
\hline $\begin{array}{l}\text { Organik Madde (\%) } \\
\text { Organic Matter }\end{array}$ & 2.19 & 2.09 \\
\hline $\begin{array}{l}\text { Toplam Azot (\%) } \\
\text { Total Nitrogen }\end{array}$ & 0.110 & 0.100 \\
\hline $\begin{array}{l}\text { Alınabilir Fosfor (mg kg-1) } \\
\text { Available Phosphorus }\end{array}$ & 33 & 18 \\
\hline $\begin{array}{l}\text { Değișebilir Potasyum }\left(\mathrm{mg} \mathrm{kg}^{-1}\right) \\
\text { Exchangeable Potassium }\end{array}$ & 188 & 160 \\
\hline $\begin{array}{l}\text { Değișebilir Kalsiyum (mg kg-1) } \\
\text { Exchangeable Calcium }\end{array}$ & 2591 & 2688 \\
\hline $\begin{array}{l}\text { Değișebilir Magnezyum (mg kg-1) } \\
\text { Exchangeable Magnesium }\end{array}$ & 240 & 247 \\
\hline $\begin{array}{l}\text { Ekstrakte Edilebilir } \mathrm{SO}_{4}-\mathrm{S}\left(\mathrm{mg} \mathrm{kg}^{-1}\right) \\
\text { Extractable Sulphur }\end{array}$ & 13.8 & 14.6 \\
\hline
\end{tabular}


$\mathrm{P}_{2} \mathrm{O}_{5}, \% 34 \mathrm{~K}_{2} \mathrm{O}$ ) ve kükürt için \%96-98 saflıkta toz kükürt kullanıımıștır.

Her iki deneme yılında, çalıșma bașlangıcında deneme alanlarından alınan karma toprak örneklerinde; bünye (Bouyoucos, 1955), pH (Pratt, 1965), EC (Anonim, 1982), kireç (Çağlar, 1958), organik madde (Anonim, 1985), toplam azot (Kacar, 1994), alınabilir fosfor (Olsen vd, 1954), değișebilir potasyum, kalsiyum, magnezyum (Anonim, 1980) ve ekstrakte edilebilir sülfat (Fox vd, 1964) analizleri yapılmıștır (Çizelge 1).

Elde edilen sonuçlara göre denemelerin kurulduğu parsel toprakları; nötr reaksiyonlu, tuzluluk problemi olmayan, organik madde içeriği orta, kireç içeriği çok az, kumlu tın ve kumlu killi tın bünyeye sahiptirler. Besin elementlerinden potasyum az, diğerleri yeterli düzeydedirler.

\section{Metot}

Soğan tohumları, iklim ve toprak șartları dikkate alınarak Mart ayında küçük el mibzeriyle ekilmiștir. Tohum ekimi yapılırken sıra arası $20 \mathrm{~cm}$ olacak șekilde çiziler çekilmiș ve açılan çiziye ekim yapıımıștır. Tohumların çıııșından sonra, bitkiler 8-10 cm boylanınca elle seyreltme yapılmıștır (yaklașık çıkıștan 1 ay sonra). Elle seyreltmede sıra üzeri $10 \mathrm{~cm}$ olacak șekilde soğan fideleri seyreltilmiștir. Seyreltme yapıldıktan sonra sıra üzeri $10 \mathrm{~cm}$, sıra arası $20 \mathrm{~cm}$ olmuștur.

Deneme, tesadüf bloklarında bölünmüs parseller deneme deseninde, 3 tekrarlamalı olarak kurulmuștur. Denemede parsel büyüklüğü 2 m x $16 \mathrm{~m}=32 \mathrm{~m}^{2}$ dir. Her parselde toplam altı sıra bulunmaktadır. Denemede gözlem, ölçüm ve analizler ortadaki 4 sırada yapılmıș, kenarda kalan sıralar kullanılmamıștır.

Her iki deneme yılında da tüm parsellere $15 \mathrm{~kg} \mathrm{da}^{-1} \mathrm{P}_{2} \mathrm{O}_{5}$ ve $10 \mathrm{~kg}^{-1}$ da $\mathrm{K}_{2} \mathrm{O}^{\prime}$ e eșdeğer MKP uygulanmıștır. Azotlu gübrenin 2/4'ü, kükürdün, fosforun ve potasyumun tamamı ekim öncesi ikinci toprak ișlemeden hemen önce uygulanmıștır. Azotlu gübrenin kalan kısmının yarısı, 3-4 gerçek yaprak döneminde (ilk yıl 06 Haziran, ikinci yıl 24 Mayıs), diğer yarısı ise baș olușum döneminde uygulanmıștır (ilk yıl 04 Temmuz, ikinci yıl 30 Haziran). Deneme alanı damla sulama yöntemiyle sulanmıștır. Denemede azot için 0-5-10-20 kg da-1 ${ }^{-1}$ kükürt için 0-2.5-5-10 kg da-1 olmak üzere 4'er farklı dozun kombinasyonları kullanılmıștır.
Soğan yapraklarının mineral madde içeriklerini belirlemek amacıyla, bașların olgunluk öncesi döneminde gelișimini tamamlamıș en genç yapraklardan örnek alınmıștır (Jones ve ark., 1991). Yaprakörnekleri; 2012 yılında 20 Temmuz, 2013 yılında ise 18 Temmuz'da alınmıștır. Yaprak örnekleri alındıktan sonra hemen laboratuvara getirilerek üzerindeki olası kalıntıları (toz, ilaç vs.) temizlemek amacıyla; teepol çözeltisiyle 1 defa musluk suyuyla, 1 defa normal su ve 2 defa da saf su ile yıkanmıștır. Suyu süzülen yapraklar; delikli kese kâğıtlarına alınarak etüve konulmuș, 60$65^{\circ} \mathrm{C}^{\prime}$ de 48 saat tutulup kuruması sağlanmıștır. Kuruyan örnekler öğütülerek analize hazır hale getirilmiștir. Öğütülmüș yaprak örneklerinin, yaș yakma $\left(\mathrm{HNO}_{3}: \mathrm{HClO}_{4} ; 4: 1\right)$ yöntemiyle ekstraktları hazırlanmıș (Kacar, 1972) ve $\mathrm{N}(\%)$ (Kacar, 1972), P (\%) (Lott ve ark., 1956), K, Ca, Mg, S (\%) (Chapman ve Prat, 1961) analizleri yapılmıștır.

Yapılan gübre uygulamalarının, verime ve kalite özelliklerine etkisinin istatistiki değerlendirilmesinde varyans analizi yapılmıștır. Bu ișlem için Jump istatistik paket programından yararlanılmıștır. Uygulamalar arasındaki ortalamaların farklılığı 0.05 önem seviyesine göre hesaplanmıștır. Ortalamalar arasındaki fark önemli çıktığında LSD testi uygulanarak farklılık seviyeleri belirlenmiștir (Yurtsever, 1984).

\section{BULGULAR VE TARTISMA}

Her iki deneme yılına ait bulgular ayrı ayrı değerlendirimiș olup; yaprakların bazı bitki besin maddesi içerikleri Çizelge $2-7$ 'de verilmiștir. Azotlu gübre uygulamaları, yaprakların azot içeriklerine her iki deneme yılında önemli etkide bulunmuș olup; artan $\mathrm{N}$ dozu ile yaprakların $\mathrm{N}$ içerikleri kontrole göre düzenli artıș göstermiș ve en

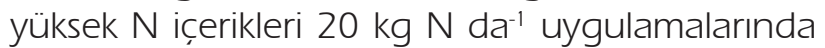
gözlenmiștir. Denemenin ilk yılında yaprakların toplam azot içerikleri \%2.61-\%3.00; ikinci yılda ise \%2.78-\%3.21 arasında değișim göstermiștir (Çizelge 2 ve Șekil 1 ).

Soğanların azot ile beslenme bakımından herhangi bir sorunu bulunmamaktadır. Her iki yılda deneme alanından alınan soğan yapraklarının azot içerikleri, azot yeterlilik sınır değeri olarak \%2.5-3.0'ü kabul eden Anonim (2014 b)'e ve \%2.0-3.0'ü kabul eden Hocmuth vd. (2004)'e göre yeterli seviyededir. 
Çizelge 2. Uygulamaların yaprakların azot (\%) içerikleri üzerine etkisi

Table 2 . The effect of applications on leaf nitrogen content $\left(\left.\%\right|^{2}\right.$

\begin{tabular}{lccccccccccc}
\hline \multicolumn{1}{c}{2012} \\
\hline & $\mathrm{N}_{0}$ & $\mathrm{~N}_{5}$ & $\mathrm{~N}_{10}$ & $\mathrm{~N}_{20}$ & Ort. & $\mathrm{N}_{0}$ & $\mathrm{~N}_{5}$ & $\mathrm{~N}_{10}$ & $\mathrm{~N}_{20}$ & Ort. \\
$\mathrm{S}_{0}$ & 2.60 & 2.73 & 2.82 & 3.02 & 2.79 & 2.78 & 2.91 & 3.02 & 3.22 & 2.98 \\
$\mathrm{~S}_{2.5}$ & 2.58 & 2.71 & 2.80 & 2.96 & 2.76 & 2.75 & 2.96 & 2.99 & 3.17 & 2.97 \\
$\mathrm{~S}_{5}$ & 2.63 & 2.63 & 2.81 & 3.01 & 2.77 & 2.81 & 2.81 & 3.00 & 3.21 & 2.96 \\
$\mathrm{~S}_{10}$ & 2.61 & 2.68 & 2.78 & 3.01 & 2.77 & 2.79 & 2.87 & 2.97 & 3.22 & 2.96 \\
Ort. & $2.61 \mathrm{~d}$ & $2.69 \mathrm{C}$ & $2.80 \mathrm{~b}$ & $3.00 \mathrm{a}$ & & $2.78 \mathrm{~d}$ & $2.89 \mathrm{c}$ & $2.99 \mathrm{~b}$ & $3.21 \mathrm{a}$ & \\
\hline
\end{tabular}

$\begin{array}{lll}\mathrm{CV}(\%) & 1.03 & 2.02\end{array}$

${ }^{2}$ Aynı sütunda veya satırda farklı harflerle ifade edilen ortalamalar arasında \%5 düzeyinde farkııık vardır.

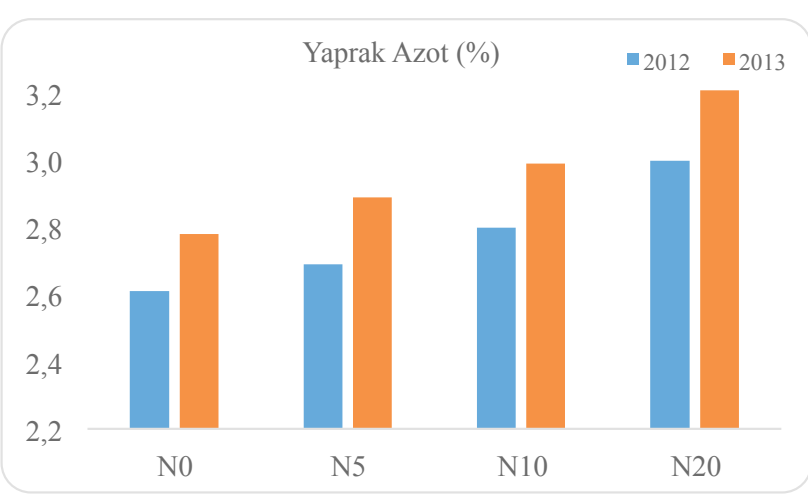

Șekil 1. Azot dozları ve yaprakların azot içerikleri

Figure 1. Nitrogen doses and the nitrogen content of onion's leaf

Azotlu gübre uygulamalarının, yaprakların fosfor içeriklerine ilk yılda etkisi önemli, ikinci yıl önemsiz olarak belirlenmiștir (Çizelge 3). Illk yıl önemli $(p<0,05)$ etkisi gözlenen azotlu gübre uygulamalarında; en yüksek fosfor içeriği \%0.19 ile $0 \mathrm{~kg} \mathrm{~N} \mathrm{da-1}$, en düșük fosfor içeriği ise \%0.16 ile $20 \mathrm{~kg} \mathrm{~N} \mathrm{da}^{-1}$ uygulamalarında belirlenmiștir. Uygulamaların önemli etkisi gözlenmeyen ikinci yılda, yaprakların $P$ içerikleri \%0.19-0.21 arasında değișim göstermiștir. Tıpkı azot gibi fosforla beslenme konusunda herhangi bir sorun belirlenmemiștir. Her iki yılda deneme alanından alınan yaprakların fosfor içerikleri de, fosfor yeterlilik sınırları Anonim (2014 b)'e göre verilen sınır değerleri (\%0.1-0.2) arasında bulunmuștur.

Gübre uygulamalarının, yaprakların potasyum içeriklerine her iki deneme yllında etkisi önemli olmamıștır. Yaprakların potasyum içerikleri; ilk yılda \%3.60-4.12 arasında, ikinci yılda ise \%3.463.94 arasında belirlenmiștir. Potasyum içerikleri bakımından en düșük ve enyüksek değerler sırasıyla; birinci yıl $\mathrm{N}_{20} \mathrm{~S}_{5}, \mathrm{~N}_{10} \mathrm{~S}_{10}$ konularında, ikinci yıl ise $\mathrm{N}_{0} \mathrm{~S}_{5}$, ve $\mathrm{N}_{5} \mathrm{~S}_{10}$ konularında tespit edilmiștir/Çizelge 4). Soğan yapraklarında potasyum için \%3.5-5.0 yeterli düzey aralığı olarak belirtilmiștir (Jones vd., 1991). Bu değerlere göre her iki yılda yaprakların potasyum içerikleri yeterli düzeyin üzerinde bulunmuștur.

Gübre uygulamalarının, yaprakların kalsiyum içeriklerine her iki deneme yllında önemli etkisi olmamıștır. Soğan yapraklarının kalsiyum içerikleri; 2012 yllinda $\% 2,85\left(\mathrm{~N}_{10} \mathrm{~S}_{2.5}\right)-3.35\left(\mathrm{~N}_{20} \mathrm{~S}_{5}\right), 2013$ de ise \%2.99 $\left(\mathrm{N}_{10} \mathrm{~S}_{5}\right)-3.41\left(\mathrm{~N}_{20} \mathrm{~S}_{2.5}\right)$ arasında belirlenmiștir (Çizelge 5). Soğan yapraklarında kalsiyum için \%1.5-2.2 yeterli düzey aralığı olarak belirtilmiștir (Jones vd., 1991). Bu değerlere göre her iki yılda yaprakların kalsiyum içerikleri yeterlilik sınır değerinin üzerinde bulunmuștur.

Çizelge 3. Uygulamaların yaprakların fosfor (\%) içerikleri üzerine etkisi

Table 3. The effect of applications on leaf phosphorus content $1 \%{ }^{2}$

\begin{tabular}{lcccccccccc}
\hline \multicolumn{10}{c}{2012} & \multicolumn{7}{c}{2013} & \\
\hline $\mathrm{S}_{0}$ & $\mathrm{~N}_{0}$ & $\mathrm{~N}_{5}$ & $\mathrm{~N}_{10}$ & $\mathrm{~N}_{20}$ & Ort. & $\mathrm{N}_{0}$ & $\mathrm{~N}_{5}$ & $\mathrm{~N}_{10}$ & $\mathrm{~N}_{20}$ & Ort. \\
$\mathrm{S}_{2.5}$ & 0.20 & 0.18 & 0.17 & 0.17 & 0.18 & 0.19 & 0.19 & 0.19 & 0.19 & 0.19 \\
$\mathrm{~S}_{5}$ & 0.19 & 0.16 & 0.17 & 0.17 & 0.17 & 0.20 & 0.20 & 0.19 & 0.20 & 0.20 \\
$\mathrm{~S}_{10}$ & 0.19 & 0.17 & 0.18 & 0.16 & 0.17 & 0.21 & 0.20 & 0.19 & 0.20 & 0.20 \\
Ort. & $0.19 \mathrm{a}$ & $0.17 \mathrm{bC}$ & $0.18 \mathrm{~b}$ & $0.16 \mathrm{C}$ & & 0.20 & 0.20 & 0.19 & 0.20 & \\
\hline $\mathrm{CV}(\%)$ & & & 3.08 & & & & & 5.58 & & \\
\hline
\end{tabular}

${ }^{2}$ Aynı sütunda veya satırda farklı harflerle ifade edilen ortalamalar arasında \%5 düzeyinde farkılık vardır. 
Çizelge 4. Uygulamaların yaprakların potasyum (\%) içerikleri üzerine etkisi

Table 4. The effect of applications on leaf potassium content $(\%)^{2}$

\begin{tabular}{lcccccccccc}
\hline \multicolumn{10}{c}{2012} & \multicolumn{10}{c}{2013} & \\
\hline & $\mathrm{N}_{0}$ & $\mathrm{~N}_{5}$ & $\mathrm{~N}_{10}$ & $\mathrm{~N}_{20}$ & Ort. & $\mathrm{N}_{0}$ & $\mathrm{~N}_{5}$ & $\mathrm{~N}_{10}$ & $\mathrm{~N}_{20}$ & Ort. \\
$\mathrm{S}_{0}$ & 3.86 & 3.81 & 3.61 & 3.97 & 3.81 & 3.53 & 3.66 & 3.73 & 3.86 & 3.69 \\
$\mathrm{~S}_{2.5}$ & 3.74 & 3.61 & 3.66 & 3.75 & 3.69 & 3.75 & 3.70 & 3.72 & 3.87 & 3.76 \\
$\mathrm{~S}_{5}$ & 3.90 & 3.67 & 3.88 & 3.60 & 3.76 & 3.46 & 3.81 & 3.83 & 3.59 & 3.67 \\
$\mathrm{~S}_{10}$ & 3.78 & 3.81 & 4.12 & 3.71 & 3.86 & 3.67 & 3.94 & 3.71 & 3.79 & 3.78 \\
Ort. & 3.82 & 3.73 & 3.82 & 3.76 & & 3.60 & 3.78 & 3.74 & 3.78 & \\
\hline CV(\%) & & & 2.68 & & & & & 4.69 & & \\
\hline
\end{tabular}

${ }^{2}$ Aynı sütunda veya satırda farklı harflerle ifade edilen ortalamalar arasında \%5 düzeyinde farklıık vardır.

Çizelge 5. Uygulamaların yaprakların kalsiyum (\%) içerikleri üzerine etkisi

Table 5. The effect of applications on leaf calcium content $(\%)^{2}$

\begin{tabular}{lcccccccccc}
\hline \multicolumn{1}{c}{2012} & \multicolumn{10}{c}{2013} \\
\hline $\mathrm{S}_{0}$ & $\mathrm{~N}_{0}$ & $\mathrm{~N}_{5}$ & $\mathrm{~N}_{10}$ & $\mathrm{~N}_{20}$ & Ort. & $\mathrm{N}_{0}$ & $\mathrm{~N}_{5}$ & $\mathrm{~N}_{10}$ & $\mathrm{~N}_{20}$ & Ort. \\
$\mathrm{S}_{2.5}$ & 3.21 & 3.16 & 2.97 & 3.32 & 3.17 & 3.23 & 3.11 & 3.05 & 3.30 & 3.17 \\
$\mathrm{~S}_{5}$ & 3.15 & 3.05 & 2.85 & 3.28 & 3.08 & 3.22 & 3.27 & 3.25 & 3.41 & 3.29 \\
$\mathrm{~S}_{10}$ & 3.11 & 3.14 & 2.87 & 3.10 & 3.05 & 3.21 & 3.34 & 3.18 & 3.20 & 3.23 \\
Ort. & 3.15 & 3.09 & 2.94 & 3.26 & & 3.24 & 3.27 & 3.12 & 3.27 & \\
\hline $\mathrm{CV}(\%)$ & & & 3.60 & & & & & 4.65 & & \\
\hline
\end{tabular}

${ }^{2}$ Aynı sütunda veya satırda farklı harflerle ifade edilen ortalamalar arasında \%5 düzeyinde farkılık vardır.

Azot ve kükürt uygulamalarının, yaprakların magnezyum içeriklerine her iki deneme ylında önemli etkisi olmamıștır. Yaprakların Mg içerikleri; 2012 yllında \%0.34-0.44 $\left(\mathrm{N}_{10} \mathrm{~S}_{10}-\mathrm{N}_{20} \mathrm{~S}_{2.5}\right), 2013$ yllinda ise \%0.36-0.39 $\left(\mathrm{N}_{10} \mathrm{~S}_{10}-\mathrm{N}_{5} \mathrm{~S}_{0^{\prime}}, \mathrm{N}_{5} \mathrm{~S}_{2.5^{\prime}}\right.$ $\mathrm{N}_{20} \mathrm{~S}_{10}$ ) aralığında belirlenmiștir (Çizelge 6). Jones vd. (1991) tarafından verilen sınır değerleriyle (\%0.25-0.40) karșılaștırıldığında, her iki yılda yaprakların toplam Mg içerikleri yeterli ve yüksek düzeylerde saptanmıștır.
Uygulamaların yaprakların kükürt içeriklerine her iki deneme yılında etkisi önemsizdir. Yaprakların kükürt içerikleri; ilk yıl \%0.53-0.79 $\left(\mathrm{N}_{20} \mathrm{~S}_{10}-\mathrm{N}_{0} \mathrm{~S}_{10}\right)$, ikinci yll ise \%0.66-0.69 (5 farklı uygulama- $\mathrm{N}_{5} \mathrm{~S}_{5}$ ) arasında tespit edilmiștir (Çizelge 7). Yapılan kükürt gübrelemesi yaprakların kükürt içeriklerini değiștirmemiștir. Kullanılan çeșidin genetik yapısından dolayı yaprakların kükürt miktarlarında farklılık önemli bulunmamıștır. Soğan yapraklarında S için \%0.5-1.0 yeterli

Çizelge 6. Uygulamaların yaprakların magnezyum (\%) içerikleri üzerine etkisiz

Table $\mathbf{6}$. The effect of applications on leaf magnesium content $(\%)^{2}$

\begin{tabular}{|c|c|c|c|c|c|c|c|c|c|c|}
\hline \multicolumn{6}{|c|}{2012} & \multicolumn{5}{|c|}{2013} \\
\hline & $\mathrm{N}_{0}$ & $\mathrm{~N}_{5}$ & $\mathrm{~N}_{10}$ & $\mathrm{~N}_{20}$ & Ort. & $\mathrm{N}_{0}$ & $\mathrm{~N}_{5}$ & $\mathrm{~N}_{10}$ & $\mathrm{~N}_{20}$ & Ort. \\
\hline$S_{0}$ & 0.43 & 0.39 & 0.36 & 0.43 & 0.40 & 0.38 & 0.39 & 0.38 & 0.37 & 0.38 \\
\hline$S_{2.5}$ & 0.39 & 0.40 & 0.35 & 0.44 & 0.40 & 0.38 & 0.39 & 0.38 & 0.38 & 0.38 \\
\hline$S_{5}$ & 0.39 & 0.38 & 0.41 & 0.39 & 0.39 & 0.37 & 0.38 & 0.38 & 0.37 & 0.37 \\
\hline$S_{10}$ & 0.38 & 0.39 & 0.34 & 0.40 & 0.38 & 0.38 & 0.38 & 0.36 & 0.39 & 0.38 \\
\hline Ort. & 3.82 & 3.73 & 3.82 & 3.76 & & 0.38 & 0.38 & 0.38 & 0.37 & \\
\hline CV $(\%)$ & & & 5.64 & & & & & 3.44 & & \\
\hline
\end{tabular}

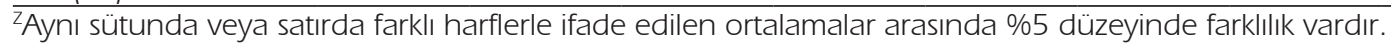


Çizelge 7. Uygulamaların yaprakların kükürt (\%) içerikleri üzerine etkisiz

Table 7. The effect of applications on leaf sulphur content $(\%)^{2}$

\begin{tabular}{lcccccccccc}
\hline \multicolumn{1}{c}{2012} & & & \multicolumn{7}{c}{2013} \\
\hline & $\mathrm{N}_{0}$ & $\mathrm{~N}_{5}$ & $\mathrm{~N}_{10}$ & $\mathrm{~N}_{20}$ & Ort. & $\mathrm{N}_{0}$ & $\mathrm{~N}_{5}$ & $\mathrm{~N}_{10}$ & $\mathrm{~N}_{20}$ & Ort. \\
$\mathrm{S}_{0}$ & 0.71 & 0.65 & 0.55 & 0.53 & 0.61 & 0.66 & 0.67 & 0.67 & 0.66 & 0.66 \\
$\mathrm{~S}_{2.5}$ & 0.71 & 0.58 & 0.59 & 0.57 & 0.61 & 0.66 & 0.68 & 0.66 & 0.68 & 0.67 \\
$\mathrm{~S}_{5}$ & 0.73 & 0.61 & 0.66 & 0.54 & 0.64 & 0.66 & 0.69 & 0.68 & 0.67 & 0.68 \\
$\mathrm{~S}_{10}$ & 0.79 & 0.59 & 0.67 & 0.50 & 0.64 & 0.67 & 0.67 & 0.67 & 0.68 & 0.67 \\
Ort. & 0.73 & 0.61 & 3.62 & 0.53 & & 0.66 & 0.68 & 0.67 & 0.67 & \\
\hline CV $(\%)$ & & & 8.51 & & & & & 2.84 & & \\
\hline
\end{tabular}

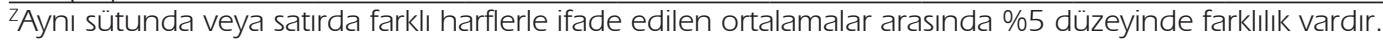

düzey aralığı olarak belirtilmiștir (Jones vd., 1991). Bu değerlere göre, her iki yılda yaprakların S içerikleri yeterli düzeyde bulunmuștur.

Soğan depolanabilen bir sebzedir. Bu nedenle bașlardaki mineral madde içeriği, özellikle de azot içeriği son derece önemlidir. Soğan bașlarında așırı azot birikimi depoda sürmeye neden olmaktadır (Kaptan vd., 1983). Kuru soğanın azotlu ve fosforlu gübre isteğinin belirlenmesi amacıyla yapılan denemede azotlu ve fosforlu gübrelerin verim üzerine etkileri önemli bulunmuștur (Demir ve Noyan, 1997). Ekonomik optimum nokta $11 \mathrm{~kg} \mathrm{~N} \mathrm{da}^{-1}$ olarak saptanmıștır. Fosforlu gübre denemeleri sonucunda toprak fosforunun etki değeri (c1) 0.207, gübre fosforunun etki değeri (c) 0.0841 , ortalama maksimum ürün ise $2344 \mathrm{~kg} \mathrm{da}^{-1}$ olarak belirlenmiștir

Soğan bașlarının olgunlașması öncesinde alınan yaprak örneklerinde; azotlu gübre uygulamalarının yaprakların azot içerikleri üzerine etkileri önemli bulunmuștur. Azotlu gübre seviyeleri arttıkça yaprakların azot içerikleri artmıștır. Azotlu gübre uygulamasıyla yaprak azot içeriği arasında doğrusal bir ilișki tespit edilmiș ve bu ilișkinin iki üretim yılında hemen hemen aynı eğilimde olduğu belirlenmiștir. Jilani vd. (2004) 3 farklı soğan çeșidinde yaptıkları çalıșmada azot dozlarının artıșıyla her üç çeșitte de yaprak uzunluğunun, toplam verimin ve yaprak $\mathrm{N}$ içeriğinin arttığını belirlemișlerdir.

Soğanda N, P, K gübrelemesi yapılan bir bașka çalıșmada maksimum verim $26.3 \mathrm{~kg}$ $\mathrm{da}^{-1} \mathrm{~N}$ dozunda ve $8.4 \mathrm{~kg} \mathrm{da} \mathrm{K}^{-1} \mathrm{~K}$ dozunda elde edilmiștir. Fosfor gübrelemesi verim üzerinde etkili olmamıștır. N, P, K gübrelemesi yaprak $N$, $P$ ve K içeriklerini attırmıștır (Boyhan vd., 2007).
Soğanda yapılan bir diğer gübreleme çalıșmasında $N$ ve $S$ gübrelemesinin yaprak sayısı, bitki boyu, soğan baș çapı, ve verimi üzerine etkili olduğu bildirilmiștir (Nasreend vd., 2007). Aynı çalıșmada gübre uygulamalarının bașların $N$ ve S alımını da arttırdığı belirlenmiștir. Soğan bașları en fazla besini $12 \mathrm{~kg} \mathrm{da}^{-1} \mathrm{~N}$ ve $4 \mathrm{~kg} \mathrm{da}^{-1}$ $S$ dozunda almıșlardır ki bu dozlar en yüksek verimin alındığı dozlardır. Soğan bașlarının besin maddesi alımında $\mathrm{N}$ ve $\mathrm{S}$ arasındaki antagonistik

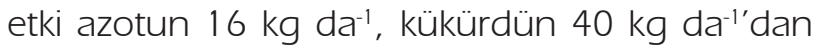
fazla kullanımında ortaya çıkmıștır.

Azotlu gübreleme ve su kullanım etkinliğinin birlikte yürütüldüğü bir bașka çalıșmada; sulamanın ve faklı azotlu gübre dozlarının șalot soğanın boyuna, yaprak sayısına, su kullanma kapasitesine, N alımına, baș sayısına, ortalama baș çapına ve verime olumlu etki yaptığı tespit edilmiștir. Su kullanımı ve azotlu gübre etkinliği arasında önemli ilișki belirlenmiștir (Kemal, 2013).

Yapılan kükürt uygulamalarının, soğan baș ve yapraklarının mineral madde (N, P, K, Ca, Mg, S) içeriğine etkilerinin istatistiksel anlamda önemsiz olduğu belirlenmiștir. Yaprak kükürt içerikleri de yapılan uygulamalardan etkilenmemiștir. Benzer șekilde Chope ve Terry (2008) de yaptıkları çalıșmada uygulanan kalsiyum ve kükürdün soğan bașlarında mineral içerik bakımından önemsiz farklara sebep olduğunu bildirmișlerdir.

Kantartopu-3 soğan çeșidi orta acı sınıfta yer alan bir çeșittir (Anonim, 2014 a). Soğana acılığı veren kükürtlü bileșiklerdir. Kullanılan çeșidin genetik olarak içerdiği kükürt miktarı fazladır. Topraktaki mevcut kükürtten faydalanabilmiștir. Chope ve Terry, (2008) de yaptıkları bir çalıșmada uygulanan kükürdün soğan bașlarında kükürt bakımından önemsiz farklara sebep olduğunu bildirmișlerdir. 


\section{SONUC}

Çalıșma, farklı azotlu ve kükürtlü gübre uygulamalarınınsoğanyapraklarınınmineralmadde içerikleri üzerine etkisinin belirlenmesi amacıyla iki üretim sezonunda yürütülmüștür. Yapılan değerlendirmeler sonucunda, soğan yaprağının azot içeriği yapılan azotlu gübre uygulamalarından etkilenerek artmıștır. Yaprakların ilk yıl fosfor içeriği de azotlu gübre uygulamasından etkilenmiștir. Gübre uygulamalarının yaprakların potasyum, kalsiyum, magnezyum ve kükürt içerikleri üzerine etkisi ise önemsiz olduğu belirlenmiștir. Soğanların beslenme durumu üzerine azot gübrelemesi etkili olurken; kükürt gübrelemesi etkili olmamıștır. Yapılan azotlu gübreleme soğan yapraklarının azot içeriklerini arttırmıștır. Azot içeriğindeki artıș, yapılan azotlu gübre dozlarındaki artıșa paralel olarak gerçekleșmiștir.

\section{TEȘEKKÜR}

Bu çalıșmanın yürütülmesi için finansman sağlayan Tarımsal Araștırmalar ve Politikalar Genel Müdürlüğü'ne ve Yalova Atatürk Bahçe Kültürleri Merkez Araștırma Enstitüsü'nün bașta idarecileri olmak üzere tüm personeline en içten teșekkürler.

\section{KAYNAKCA}

Aksoy M (2010). Kanser ve Beslenme, Hacettepe Üniversitesi Beslenme ve Diyabetik Bölümü. http://www. ukdk.org/pdf/kitap/14.pdf (Erișim Tarihi: 04 Ocak 2010).

Al-Fraihat A H (2009). Effect of Different Sulfur and Nitrogen Fertilizer Levels on Growth, Yield and Quality of Onion, Jordan Journal of Agricultural Sci., Vol.5, No:2.

Anonim (1980). Soil and Plant Testing and Analysis as a Basis of Fertilizer Recommendations. F.A.O., Soils Bulletin 38/2, p:95.

Anonim (1982). Methods of Soil Analysis Ed.: A. L. Page. Number 9. Part II. Madison, Wisconsin. USA.

Anonim (1985). Agricultural Analysis Handbook. Hach Company 22546-08, p:65-69.

Anonim (2007). Soğan Yetiștiriciliği, Tarım ve Köyișleri Bakanlığı Çiftçi Eğitim Serisi Yayın No. 57.

Anonim (2014 a). Sebze Çeșitleri, http://yalovabahce. gov.tr/sebzecesit.aspx (Erișim Tarihi: 18 Ekim 2013).

Anonim (2014 D). Onion Leaf Analysis Guide for Diagnosis Crop Nutrient Status http://vric.ucdavis.edu/veg_ info/onion_leaf_analysis.htm (Erișim Tarihi: 24 Nisan 2014).

Anonim (2017 a). FAO Stat Crop Production, http:// faostat3.fao.org/faostat-gateway/go/to/ download/q/qc/e (Erișim Tarihi: 12 Șubat 2017).

Anonim (2017 b). Bitkisel Üretim ve i̇statistik Veri Tabanı, http://tuikapp.tuik.gov.tr/bitkiselapp/ bitkisel.zul (Erișim Tarihi: 17 Șubat 2017).
Beșirli G, Sönmez I, Albayrak B, Rușen M, Çakır E, Maden S, Barıș A, Kepenekçi I, Evlice E. ve Karataș S E (2007). Soğan Yetiștiriciliği, Tarım ve Köyișleri Bakanlığı Çiftçi Eğitim Serisi Yayın No. 57.

Bloem E, Haneklaus S and Schung E (2004). Influence of $\mathrm{N}$ and S Fertilization on the Alliin Content of Onions and Garlic, J. of Plant Nut. Vol:7, No:10, p:1827-1839.

Bouyoucos G J (1955). A Recalibration of the Hydrometer Method for Making Mechanical Analysis of the Soils. Agronomy Journal, 4(9).

Boyhan E, Torrance R L, and Hill C R (2007). Effects of Nitrogen, Phosphorus and Potassium Rates and Fertilizer Sources on Yield and Leaf Nutrient Status of Short-Day Onions, Hort Science: 42(3):653-660.

Brown B (2000). Onions. Southern Idaho Fertilizer Guide, CIS 1081, University of Idaho.

Çağlar K Ö (1958). Toprak Bilgisi. A. Ü. Z. F. Yayınları, Yayın No:10. s:286.

Chapman H D and Pratt PF (1961). Method of Analysis for Soils, Plant and Waters. University of California, Division of Agricultural Science. 1-6.

Chope G A and Teryy L A (2008). Use of Canonical Variate Analysis to Differentiate Onion Cultivars by Mineral Content as Measured by ICP-AES, Food Chemistry, Volume 115, Issue 3.

Demir M ve Noyan Ö F (1997). Tokat ve Amasya Yöresi Sulu Koșullarında Kuru Soğanın Azotlu ve Fosforlu Gübre İsteği, K. H. A. E., Genel Yayın No: 102, Tokat.

Fox R L, Olson R A and Rhoades H F (1964). Evaluating the Sulfur Status of Soils by Plant and Soil Tests. Soil Sci. Soc. Am. Proc. 281. p:435-439.

Hochmuth G, Maynard D, Vavrina C, and Simonne E (2004). Plant Tissue Analysis and Interpretation for Vegetable Crops in Florida1. http://edis.ifas.ufl.edu/ pdffiles/ep/ep 08100.pdf (Erișim Tarihi: 24 Nisan 2014).

Jilani M S, Ghaffoor A, Waseem K and Farooqi J I (2004). Effect of Different Levels of Nitrogen on Growth and Yield of Three Onion Varieties, Int. J. Agri. Biol., Vol. 6, No:3.

Jones Jr J B, Wolf B and Mills H A (1991). Plant Analysis Handbook. Micro-Macro Publishing, Inc. U. S. A. p:1-213.

Kacar B (1972). Bitki ve Toprağın Kimyasal Analizleri: II. Bitki Analizleri. Ankara Üniversitesi Ziraat Fakültesi Yayınları, Yayın No: 453.

Kacar B (1994). Bitki ve Toprağın Kimyasal Analizleri: III. Toprak Analizleri. Ankara Üniversitesi Ziraat Fakültesi Eğitim, Araștırma ve Geliștirme Vakfı Yay. No: 3.

Kaptan H, Türkeș N ve Kaynaș K (1983). Soğanın Ticari Gübre İsteği ve Beslenmenin Dayanıklıık Üzerine Etkisinin Saptanması, Atatürk Bah. Kül. Ar. Ens., Yalova.

Kawakishi S and Morimutsu Y (1994). Sulfur Chemistry of Onions and Inhibitory Factors of the Arachidonic-Acid Cascade, ACS SYM. SER. 546, p:120-127. 
Kemal Y O (2013). Effects of Irrigation and Nitrogen Levels on Bulb Yield, Nitrogen Uptake and Water Use Efficiency of Shallot (Allium cepa var. ascalonicum Baker), African Journal of Agricultural 8(37): 4637- 4643. http://academicjournals. org/article/article 1380905577_kemal.pdf

Korkmaz A ve Saltalı K (2012). Bitki Besin Elementi Yarayıșlıı̆ı̆ını Etkileyen Faktörler, Bitki Besleme, GÜBRETAȘ Rehber Kitaplar Dizisi:2, s.93-123.

Krishnamatuhy D and Sharanappa S (2005). Effect of Sole and Integrated Use of Improved Composts and NPK fertilizers on Quality, Productuvity and Shelf Life Bangalore Rose Red Onion (Allium cepa L. ), Mysore J. of Agric. Sci. 39(3):355-361.

Lawande K E (2010). Onion, National Research Centre for Onion and Garlic, Pune. http://obtrando.files.wordpress. com/2010/05/allium-sp-onion-keluarga-bawang-merah. pdf (Erișim Tarihi: 02 Kasım 2010).

Lott W L, Gallo J P and Medaff J C (1956). Leaf Analysis Technic in Coffee Research. Ibec. Research Institute II: p:2124.

Marschner H (1998). Mineral Nutrition in Higher Plants, Academic Pres, Harcourt Brace Jovanovich Publisher, 674.

McCallum J, Porter N, Searle B, Shaw M, Bettjeman B and McManus M (2005). Sulfur and Nitrogen Fertility Affects Flavour of Field-Grown Onions, Plant and Soil (2005) 269, p:151-158.

Mengel K and Kirkby E A (2001). Principles of Plant Nutrition, 5th Edition, Kluwer Academic Pub., London.
Nasreen S, Haque M M, Hossain M A and Farid A T M (2007). Nutrient Uptake and Yield of Onion as Influenced by Nitrogen and Sulphur Fertilization, Bangladesh J. of Agric. Res. 32(3):413-420.

Olsen S R, Cole V, Watanabe F S and Dean L A (1954). Estimation of Available Phosphorus in Soils by Extraction with Sodium Bicarbonate. U. S. D. A. Circular no. 939. Washington D. C.

Pratt PF (1965). Methods of Soil Analysis. Part 2. Chemical and Microbiological Properties. Ed. C. A. Black. Amer. Soc. Agr. Inc. Pub. Agron. Series No: 9, Madison, Wisconsin, USA.

Randle W M (1992). Onion Germplam Interacts With Sulfur Fertility for Plant Sulfur Utilization and Bulb Pungency, Euphytica, 59, p:151-156.

Randle W M (2000). Increasing N Concentration in Hydroponic Solutions Affects Onion Flavor and Bulb Quality, J. Am. Soc. Hort. Sc. 181 p:254-259.

Robinowitch H D and Brewster J L (1990). Onions and Allied Crops, Vol. I, CRC Pres, Boca Raton, Florida.

Tiwori R S, Ankur A and Sengar S C (2002). Effect of Doses and Method of Nitrogen Aplication on Growth, Bulb Yield and Quality of Onion, Indian J.of Agric. Sci. 72(1):23-25.

Yurtsever N (1984). Deneysel İstatistik Metodlar. Köy Hizmetleri Genel Müd., Toprak ve Gübre Araștırma Enst. Yayın No 56, Ankara. 